\title{
TIPOLOGI SOSIAL BUDAYA MASYARAKAT NELAYAN DI NEGERI LATUHALAT, AMBON
}

\author{
"Nendah Kurniasari dan Christina Yuliaty \\ Balai Besar Penelitian Sosial Ekonomi Kelautan dan Perikanan \\ Gedung Balitbang KP I Lt. 4 \\ Jalan Pasir Putih Nomor 1 Ancol Timur, Jakarta Utara \\ Telp: (021) 64711583 Fax: 64700924 \\ *e-mail: nendahkurniasari@gmail.com \\ Diterima 12 Februari 2014- Disetujui 25 Mei 2014
}

\begin{abstract}
ABSTRAK
Pengetahuan mengenai tipologi bsosial budaya suatu masyarakat merupakan faktor pendukung keberhasilan program pembangunan perikanan. Makalah ini bertujuan untuk menganaisis tipologi sosial budaya masyarakat nelayan di Negeri Latuhalat Kota Ambon. Penelitian dilaksanakan pada Tahun 2013 Di Nagari Latuhalat Kecamatan Nusasiwe Kota Ambon. Data yang diambil adalah data primer dan sekunder melalui wawancara mendalam dengan tokoh masyarakat, aparat pemerintahan desa, perguruan tinggi dan Dinas Kelautan dan Perikanan Kota Ambon. Data dianalisis secara deskriptif kualitatif. Hasil penelitian menunjukkan bahwa Masyarakat nelayan di negeri latuhalat masuk kedalam masyarakat transisi. Masyarakat tersebut memiliki ciri-ciri sebagai masyarakat tradisional pedesaan yang ditunjukkan dengan kolektifitas yang tinggi, struktur ekonomi lokal yang mendorongt pada kecenderungan ekonomi pertukaran, dan mampu memenuhi pra syarat dari masyarakat industri, seperti kemampuan berinvestasi, tidak mudah menyerah, kemampuan adaptasi dan inovasi. Berdasarkan hal tersebut maka diperlukan kebijakan yang mendukung pendidikan, akses permodalan, dan akses pasar barang produksi sebagai entry point upaya perbaikan dan rekayasa sosial pada masyarakat di Negeri Latuhalat.
\end{abstract}

Kata kunci: sosial budaya, nelayan, masyarakat

\section{Abstract : Typology of Social Culture the Fishery Community In Latuhalat Village , Ambon. by: Nendah Kurniasari dan Christina Yuliaty}

Knowledge of socio-cultural typology in a society is one of supporting factor for the success of fisheries development program. This paper aims to analyze the socio-cultural typology of fishing communities in Latuhalat Village, Ambon City. The research was conducted in 2013 at the Latuhalat village Nusasiwe District of Ambon City. Data is taken from primary and secondary data through in-depth interviews with community leaders, village government officials, universities and the Department of Marine and Fisheries Ambon City. Data were analyzed by descriptive qualitative. The results showed that the fishery communities in Latuhalat included in transition society. These communities have characteristics that are in between the traditional rural communities with high collectivity characterized, the structure of the local economy in the form of exchange and other economic trends; also has the characteristics of being a pre requisite of industrial society, such as the ability to invest, persistent, adaptability and innovation. Based on this it is necessary policies that support education, access to capital, and market access of goods production as an entry point improvement and social engineering on society in the Latuhalat.

Keywords : typology of social culture, fishery community

\section{PENDAHULUAN}

Industrialisasi Kelautan dan Perikanan merupakan suatu konsep yang diusung oleh Kementrian Kelautan dan Perikanan dalam mendorong percepatan dan perluasan pembangunan ekonomi nasional, khususnya pembangunan kelautan dan perikanan. Pencapaian tujuan industrialisasi tersebut dilakukan oleh Kementerian Kelautan dan Perikanan dengan memposisikan para pelaku usaha bidang kelautan dan perikanan sebagai subjek yang memberdayakan komoditas kelautan dan perikanan dari sektor hulu sampai sektor hilir (KKP, 2012).

Keberhasilan pembangunan perikanan membutuhkan perubahan cara pandang dan perilaku seluruh komponen bangsa (Anonimous, 2011). Terkait dengan perubahan cara pandang dan perilaku maka aspek sosio-budaya merupakan aspek penting yang harus diperhatikan. Hal ini atas pertimbangan bahwa tindakan ekonomi terlekat secara nyata dan terus menerus dalam suatu sistem hubungan sosial (Granoveter, 1992).

Salah satu proposisi dalam tindakan ekonomi adalah bahwa aktivitas industrialisasi- terbentuk karena bekerjanya kekuatan faktor sosial secara terus menerus. Dalam proses industrilasiasi tersebut, faktor budaya menempati posisi penting dalam ekonomi. Menurutnya, keterlekatan tidak hanya menyangkut aspek sosial tapi juga pada level politik, budaya, dan pengetahuan. Budaya memberikan kategori-kategori yang memampukan kita untuk turut serta dalam tindakan ekonomi tetapi juga dapat menghambat (Damsar, 2002). Oleh karenanya 
pertimbangan aspek sosial budaya menjadi prasyarat dalam upaya rekayasa perilaku kolektif masyarakat ke arah yang lebih produktif.

Berdasarkan hal tersebut, penelitian ini bertujuan mempelajari kondisi tipologi sosial budaya masayarakat di sebuah sentra perikanan di Kota Ambon yaitu Negeri Latuhalat. Kajian ini menjadi penting, karena pengetahuan mengenai tipologi sebuah masyarakat menjadi dasar menentuan kebijakan terkait dengan bentuk, sasaran, dan waktu intervensi yang harus dilakukan bagi perubahan perilaku masyarakat menuju era industrialisasi perikanan. Kebijakan yang dihasilkan diharapkan cenderung menekankan konsep industrialisasi yang humanis dimana aktivitas ekonomi yang dilakukan nelayan tidak semata-mata dipandang sebagai upaya memenuhi kebutuhan dasar hidup, namun merupakan bentuk aktualisasi kesadaran diri manusia dalam menekuri hidup dan penghidupannya.

\section{METODE PENELITIAN}

\section{Waktu dan Lokasi Penelitian}

Penelitian dilaksanakan pada Januari sampai dengan Desember 2013 di Negeri Latuhalat, Kota Ambon. Penetapan lokasi ini didasarkan pada pertimbangan bahwa lokasi tersebut merupakan sentra perikanan di Kota Ambon.

\section{Jenis dan Sumber Data}

Data yang digunakan dalam penelitian ini adalah data primer yang dikumpulkan melalui wawancara mendalam dengan informan yaitu pelaku usaha (nelayan, pembudidaya, pengolah, pedagang), pemuka masyarakat, aparat pemerintah, dan perguruan tinggi. Data yang dikumpulkan terkait dengan struktur dan kultur masyarakat di lokasi penelitian. Struktur meliputi pelapisan berdasarkan penguasaan aset produksi, pembagian kerja, pola hubungan kerja, pola hubungan pemasaran, pola hubungan iput produksi dan pola hubungan permodalan. Data mengenai kultur yang dikumpulkan mengenai pola pewarisan, perilaku ekonomi: etos kerja dan motif ekonomi.

\section{Metode Analisis Data}

Data dianalisis menggunakan pendekatan deskriptif. Analisis deskriptif memberikan gambaran pola-pola yang konsisten dalam data, sehingga hasilnya dapat dipelajari dan ditafsirkan secara singkat dan penuh makna (Kuncoro, 2009). Dalam analisis deskriptif, dilakukan interprestasi atas data dan hubungan yang ada dalam penelitian tersebut. Di samping itu juga dilakukan perbandingan antara hasil penelitian yang dilakukan ini terhadap hasil-hasil penelitian terkait dan dikaitkan pula dengan teori atau konsep yang relevan (Singarimbun dan Effendi, 1989).
Analisis data didasari oleh penggunaan paradigma penelitian kritis. Penggunaan paradigma ini didasari atas tujuan mengungkap hal-hal yang tersembunyi dari setiap fenomena sosial budaya masyarakat yang diteliti. Tipologi sosial budaya dalam makalah ini mencakup aspek struktur dan kultur pada masyarakat terkait dengan aktivitas nafkah mereka sebagai nelayan. Struktur sosial masyarakat dan hal-hal yang ada dibaliknya diungkap menggunakan pendekatan moda produksi. Sementara terkait dengan kultur masyarakat dan hal-hal yang ada dibaliknya akan diungkap menggunakan konsep stratifikasi sosial dari Weber terutama mengenai status sosial. Penentuan tipologi masyarakat, didasarkan pada hasil analisis struktur dan kultur masyarakat. Tipologi mayarakat yang digunakan dalam penelitian ini terbagi menjadi tipologi masyarakat tradisional, masyarakat transisi dan masyarakat modern.

\section{HASIL DAN PEMBAHASAN}

\section{Pola Hubungan Produksi dan Pemanfaatan Teknologi}

Wilayah Kota Ambon memiliki karakteristik geografis yang unik, kota ini merupakan sebuah daratan berbukit yang subur dan diapit oleh dua perairan yaitu TelukAmbon dan LautBanda. Olehkarenanya sumberdaya alamnya memiliki karakteristik yang khas yaitu pertanian dan perikanan, sehingga mata pencaharian masyarakat yang dominan adalah pemanfaat sumberdaya tersebut yaitu sebagai petani dan nelayan. Komoditas pertanian yang dihasilkan cukup beragam baik hasil tanaman pangan maupun hortikulturan, diantaranya yaitu sagu, padi, kopi, jagung, kacang, gandaria, dan pisang. Sedangkan hasil perikanannya pun cukup beragam baik ikan pelagis, demersal maupun ikan karang. Selain itu, banyak pula petani dan nelayan yang mempunyai penghasilan tambahan sebagai pembuat batu bata. Tidak jarang, masyarakat di Latuhalat membuat batu bata sendiri untuk membuat rumahnya.

Sebagai wilayah yang diapit oleh dua perairan dengan karakteristik yang berbeda, yaitu laut Banda yang merupakan laut dalam dengan potensi ikan demersal yang sangat melimpah dan teluk ambon dengan kondisi yang lebih tenang kaya akan ikan-ikan pelagis yang dapat diambil sepanjang tahun. Salah satu daerah sentra perikanan di Kota Ambon adalah Kecamatan Nusaniwe. Jika dilihat dari jumlah nelayan dan RTP di Kota Ambon maka Kecamatan Nusaniwe merupakan kecamatan dengan jumlah nelayan dan RTP terbanyak diKota Ambon.

Alat tangkap yang umumnya digunakan oleh nelayan di Kota Ambon adalah Giob (Bobo), Jaring Insang Besar, Jaring insang Kecil, Pancing, Pancing Tonda dan Bagan. Giob adalah sejenis mini purse seine yang banyak digunakan oleh nelayan. Di Desa Latuhalat, alat tangkap yang dominan adalah giob dan pancing tonda. 
Tabel 1. Jumlah Nelayan dan RTP di Kota Ambon Tahun 2010.

\begin{tabular}{clcc}
\hline No & \multicolumn{1}{c}{ Kecamatan } & Jumlah Nelayan & Jumlah RTP \\
\hline 1 & Teluk Ambon & 683 & 595 \\
2 & Teluk Ambon Baguala & 822 & 726 \\
3 & Sirimau & 375 & 294 \\
4 & Leitimur Selatan & 617 & 548 \\
5 & Nusaniwe & 1.329 & 1.224 \\
\hline \multicolumn{2}{r}{ Jumlah } & $\mathbf{3 . 8 2 6}$ & $\mathbf{3 . 3 8 7}$ \\
\hline
\end{tabular}

Sumber : Dinas Perikanan dan Kelautan Kota Ambon, 2010.

Nelayan di desa Latuhalat umumnya merupakan nelayan oneday fishing, yang berangkat sekitar jam dua malam dan pulang sekitar jam 10 pagi. Zona penagkapannya lebih dari dari 10 mil ke arah pulau Lusipara. Ikan hasil tangkapan mereka adalah cakalang, komo (tongkol), dan momar. Ikan tersebut kemudian akan dijual kepada jibu-jibu. Tidak jarang jibu-jibu tersebut adalah para istri dari juragan kapal.

Kapal yang digunakan oleh nelayan bobo/giob gunakan disebut bodi bobo yang mempunyai kapasitas 5 GT dan mesin 15 PK. Dengan kapal ini mereka bisa mengarungi laut Banda dengan leluasa, tidak seperti hal perahu katingting dan perahu penggayuh yang sering digunanakan oleh nelayan dengan alat tangkap pancing. Namun demikian perahu katingting dan perahu penggayuh juga sering dipakai menangkap ikan di laut banda namun dengan jarak yang lebih pendek dan pada musim angin Timur. Pada musim Barat mereka kembali menangkap di perairan Teluk Ambon.

Nelayan pengayuh dalam sehari dua kali trip yaitu pagi jam 04.30 WIT sampai dengan jam 10.00 WIT dan sore hari berangkat jam 15.00 WIT sampai dengan jam 18.00 WIT. Pertimbangan penentuan jam berangkat adalah karena menurut perkiraan mereka pada saatsaat tersebut ikan sedang dalam kondisi lapar sehingga umpan mereka akan banyak dimakan. Hasil tangkapan nelayan ini adalah selar (tolinya), cakalang. Ikan hasil tangkapan ada yang langsung dijual ke jibu-jibu (bakul ikan) ada juga yang melalui tukang lelang yang akan dijual ke pasar.
Kapal atau perahu yang dominan digunakan oleh nelayan di Desa Latuhalat adalah bodi bobo, katingting dan perahu penggayuh. Bodi bobo adalah kapal yang menggunakan alat tangkap purseseine memiliki panjang $15 \mathrm{~m}$ dan lebar $3 \mathrm{~m}$, sementara perahu katingting mempunyai lebar $80 \mathrm{~cm}$, panjang 3,5 meter dan tinggi $60 \mathrm{~cm}$. Katingting dilengkapi dengan sayap dan mesin tempel. Sementara perahu penggayuh atau jukung mempunyai panjang 3,5 meter lebar $35 \mathrm{~cm}$ dan tinggi $35 \mathrm{~cm}$.

Alat tangkap yang digunakan oleh nelayan bodi bobo adalah bobo atau giob atau mini purseseine yang dibantu oleh rumpon. Bobo memiliki panjang $250 \mathrm{~m}$ yang digunakan pada kedalaman $50 \mathrm{~m}$. Sementara nelayan yang menggunakan perahu adalah nelayan pancing dan pancing tonda. Nelayan pancing mempunyai kreatifitas tersendiri dalam membuat umpan. Mereka memodifikasi umpan berdasarkan pengalaman yang mereka alami dalam menangkap ikan dan berdasarkan petunjuk dari orang tua mereka yang bermata pencaharian sebagai nelayan juga. Beberapa umpan hasil modifikasi tersebut diantaranya adalah cabu cabu, tatihu dan umpan pentil.

Cabu-cabu sudah dimodifikasi dari bentuk asli yang mereka dapatkan dari nenek moyang mereka. Jika dahulu terbuat dari bulu ayam, maka sekarang dari nilon dikarenakan nilon lebih mudah diperoleh dan tidak membutuhkan proses pengecatan. Bulu ayam selain memerlukan pengecatan juga saat ini sudah sulit untuk didapatkan. Cabu-cabu digunakan untuk mata kail pancing untuk menangkap ikan tuna. Selain itu, cabu-

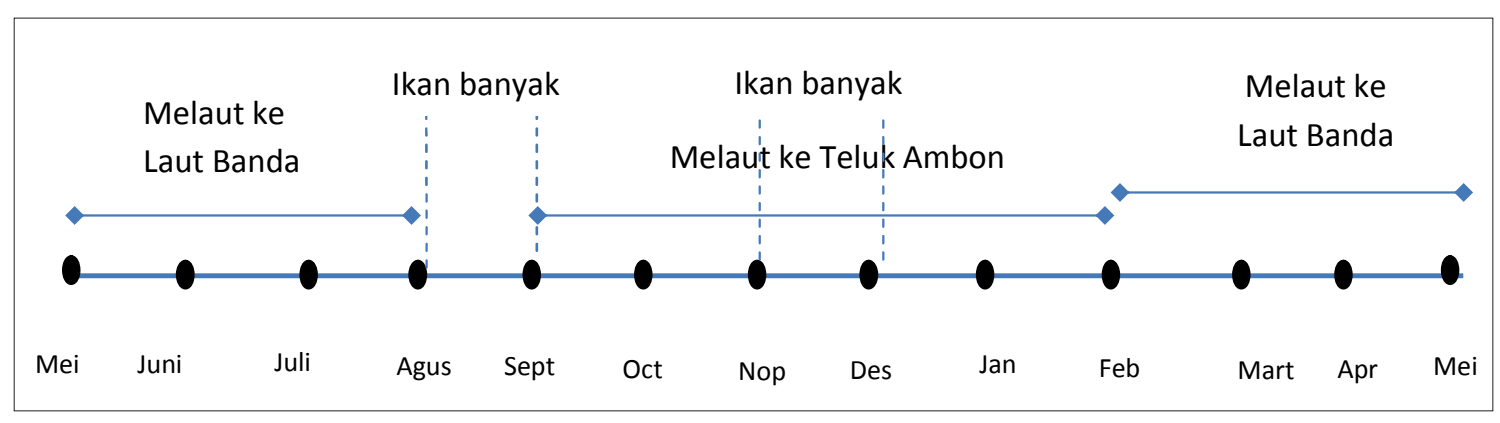

Sumber: pemetaan partisipatif antara peneliti dengan nelayan

Gambar 1. Kalender Musim Penangkapan Ikan di Desa Latuhalat Kecamatan Nusaniwe 
cabu digunakan juga untuk menangkap beberapa jenis ikan tergantung warna dari rumbai nilonnya. Warna merah untuk menangkap ikan sontong (sotong), warna biru untuk ikan kepala paku dan ikan tuing-tuing (sejenis ikan terbang) serta warna kuning untuk menangkap ikan tatui. Sementara tatihu adalah umpan tiruan yang berbentuk seperti udang yang digunakan untuk menangkap cumi.

Sumber modal nelayan pada umumnya berasal dari modal sendiri baik itu nelayan giob maupun nelayan pancing. Ukuran skala usaha berdasarkan jumlah modal sendiri yang dimiliki, dan untuk memperbesar usaha dilakukan dengan cara menabung atau menjual aset usaha yang lain. Mereka tidak terbiasa menabung ataupun mengajukan pinjaman ke bank untuk memperbesar usahanya. Seorang nelayan juragan jaring bobo bernama Pt (45 tahun) mengungkapkan bahwa ia menjual enam buah oto (angkot) nya untuk membeli bodi bobo beserta perlengkapannya. Satu buah bodi bobo beserta perlengkapannya dengan harga berkisar Rp 500-600 juta. Tindakan tersebut mencerminkan dua hal. Pertama, Pt menganggap bahwa dengan modal sendiri resiko yang akan ditanggung jika terjadi musibah lebih kecil dibandingkan dengan resiko bila meminjam dari pihak lain (lembaga keuangan yang mengenakan bunga). Kedua, bahwa usaha perikanan tangkap dengan bodi bobo dianggap lebih menguntungkan dari pada usaha di bidang angkutan darat (oto).

Lain halnya dengan AM (55 tahun), awalnya beliau hanya seorang tanase (kapten) dari kapal milik orang lain. Sebagian upah dari pekerjaannya sebagai tanase ia tabung, setelah 20 tahun hasil tabungannya ditambah dengan uang hasil usaha istrinya sebagai jibujibu cukup untuk membeli sebuah bodi bobo beserta perlengkapannya.

'beli kapal modal sendiri...Maitua (istri saya) nabung, jadi jibu-jbu, sampai bisa beli kapal begini ditambah dengan tabunganku selama jadi tanase. Satu hari seurat benang, lama-lama menjadi kain'

Hal yang menarik, AM beserta istrinya tidak menabung di bank atau lembaga keuangan lainnya, namun di dalam jelisgen (tempat menyimpan air/ minyak) yang disimpan di dalam kamarnya, dengan alasan jika sewaktu-waktu membutuhkan uang, tidak perlu ke bank. Selain itu menurut beliau, disimpan di rumah pun aman karena selama ini tidak pernah ada kasus pencurian. Sekarang AM sudah memiliki 4 buah bodi bobo. Bodi yang pertama, beliau buat sendiri dengan bahan-bahan yang dia kumpulkan sedikit demi sedikit sehingga beliau hanya mengeluarkan biaya sebesar Rp 80 juta untuk kapal pertamanya.

Sistem bagi hasil yang diterapkan pada bodi bobo adalah hasil penjualan (pendapatan kotor) dikurangi perbekalan akan didapatkan hasil bersih yang akan dibagi menjadi $30 \%$ untuk bensin dan minyak tanah dan 70\% nya dibagi 3 bagian yaitu untuk tanase-masnait, rumpon dan bodi kapal. Bagian tanase dan masnait dibagi menjadi 21 bagian jika ABK sejumlah 20 orang. Tanase mendapatkan 2 bagian sementara masnait masing-masing mendapatkan satu bagian.

Antara pemilik kapal dengan anak buah kapal(ABK) biasanya terdapat ikatan berupa perjanjian/ kontrak kerja yang tidak tertulis yang mengharuskan ABK bekerja selama minimal 1 tahun. Jika terjadi pelanggaran terhadap kontrak kerja tersebut tidak akan mendapatkan bingkisan hari raya berupa beras, kue kaleng dan sprei. Agar ABK betah bekerja, Tanase harus adil dalam pembagian pekerjaan dan penghasilan.

Sistem kekerabatan masyarakat di Latuhalat, seperti halnya pada Orang Ambon pada umumnya, menganut sistem patrilineal, dimana garis keturunan ditarik dari pihak laki-laki. Sistem kekerabatan tersebut mewarnai pola tempat tinggal dan pola pewarisan. Mereka tinggal menetap berdasarkan kekerabatan pihak laki-laki (patrilokal). Pola pewarisan pada masyarakat Latuhalat mengikuti sistem kekerabatan dimana diturunkan kepada pihak laki-laki, sementara pihak perempuan hanya memiliki hak pakai terhadap harta warisan

Terdapat dua jalur pemasaran ikan hasil tangkapan yaitu langsung dijual ke jibu-jibu atau dipercayakan dulu kepada tukang lelang untuk kemudian dijual ke pasar. Jika langsung dijual ke jibu-jibu maka nelayan (tonasa) akan langsung menerima uang hasil penjualan dan mengatur pembagiannya. Jika dipercayakan dulu ke tukang lelang, maka uang hasil penjualan akan diterima setelah tukang lelang menjualnya ke pasar, baru diberikan ke tonasa untuk diatur pembagiannya. Dalam hal ini, tukang lelang akan mendapatkan keuntungan 10 $\%$ dari seluruh hasil penjualan.

Pertimbangan nelayan memilih tukang lelang sebagai perantara dalam memasarkan ikan dibandingkan dengan jibu-jibu adalah harga jual ikan di tukang lelang berdasarkan harga ikan di pasar tujuan. Sementara harga jual di jibu-jibu ditentukan sepihak oleh jibu-jibu itu sendiri. Keuntungan menjual hasil tangkapan ke jibujibu adalah uang hasil penjualan langsung diterima oleh nelayan, sedangkan jika dijual melalui tukang lelang uang hasil penjualan diterima setelah ikan terjual. Namun demikian biasanya keuntungan dari penjualan melalui tukang lelang lebih besar dibandingkan jika dijual ke jibu-jibu.

Hal yang menarik dari mekanisme pemasaran ikan di Latuhalat adalah sebelum terjadi konflik Ambon 1999, yang berprofesi sebagai jibu-jibu adalah para perempuan Buton, namun pascakonflik, masyarakat Bugis banyak yang meninggalkan Latuhalat. Kondisi ini dimanfaatkan oleh istri-istri nelayan lokal untuk mengisi peluang usaha sebagai jibu-jibu. Hal ini juga didorong oleh memburuknya kondisi perekonomian lokal akibat 
konflik. Dengan demikian istri nelayan mempunyai peran penuh dalam pengelolaan keuangan sehingga menghindari timbulnya kecurigaan istri terhadap suami. Namun penjualan dari ikan cabut/ ikan makan (ikan sampingan) bukan merupakan hak istri tapi hak suami. Peran istri nelayan sebagai jibu-jibu ini turut berperan dalam menciptakan harmonisasi dan keberlangsungan kehidupan rumah tangga nelayan.

Tukang lelang mayoritas berasal dari suku Makassar, Buton, dan Bugis. Orang Ambon tidak banyak yang menjadi tukang lelang dikarenakan mereka merasa tidak pandai berjualan untuk kapasitas yang besar, sehingga mereka merasa cukup menjadi jibu-jibu. Tetapi hal ini tidak menutup kemungkinan, kedepannya Orang Ambon mahir berjualan dan menjadi tukang lelang mengingat sekarang banyak jibu-jibu yang dilakukan oleh Orang Ambon yang sebelumnya dilakukan oleh Orang Bugis.

Ikan hasil tangkapan nelayan dijual dengan menggunakan ukuran loyang (baskom) yang berukuran 20 liter. Jibu-Jibu mulai bekerja dari jam 07.00 wita menunggu ikan didaratkan di samping PPI Eri hingga jam 11.00 wita. Setelah itu para jibu-jibu melanjutkan pekerjaannya menjual dagangan mereka di pasar Arumbai hingga pukul 16.00 wita bahkan terkadang hingga pukul 18.00 wita. Para jibu-jibu tidak pernah membawa ikan hasil dagangan mereka pulang ke rumah. Artinya semua ikan dagangannya harus habis terjual di pasar meskipun terkadang mereka harus menjual ikan sisa tersebut dengan harga pembelian.

Moda produksi yang terjadi di dalam aktivitas nafkah masyarakat nelayan Latuhalat adalah moda produksi perikanan tangkap. Aktor yang terlibat di dalamnya, seperti telah dijelaskan sebelumnya, adalah nelayan pemilik, buruh nelayan, pedagang pengumpul dan pedagang pengecer. Faktor modal dan teknologi merupakan unsur utama di dalam force of production. Namun berbeda halnya dengan lokasi penelitian lainnya, faktor kapital lebih banyak berasal dari nelayan sendiri yaitu nelayan pemilik dibandingkan dengan bergantung pada pihak ketiga. Teknologi yang digunakan ditentukan oleh kekuatan kapital (modal) yang dimiliki oleh nelayan pemilik. Jadi, faktor kapital (modal) lebih mendominasi dibandingkan dengan faktor teknologi.

Relasi produksi (relation of production) yang terjadi pada moda produksi perikanan tangkap di nelayan Latuhalat terjadi dalam dua tingkatan. Kedua tingkatan relasi produksi tersebut adalah relasi antara pemilik dengan buruh nelayan, sesama buruh nelayan dan antara pemilik dengan pedagang ikan. Relasi produksi yang terjadi diantara pemilik dengan buruh nelayan didasarkan atas perbedaan kekuatan modal, pemilik menguasai modal finansial dan teknologi, sementara buruh nelayan menguasai modal tenaga serta pengetahuan. Relasi yang terjadi diantara buruh nelayan didominasi oleh perbedaan pengetahuan tentang teknik penangkapan yang diperoleh melalui pengalaman bertahun-tahun. Sementara relasi yang terjadi antara nelayan pemilik dengan pedagang adalah adanya perbedaan penguasaan jenis akses. Dalam hal ini nelayan pemilik menguasai akses atas hasil barang produksi (ikan tangkapan), sementara pedagang menguasai akses dan informasi pasar.

Seperti diketahui bahwa dalam relasi antara nelayan pemilik dengan nelayan buruh keseluruhan, meskipun seolah-olah keduanya saling bergantung karena memiliki dua jenis modal yang berbeda namun faktor modal finansial lebih dominan. Modal tenaga dan pengetahuan bukan merupakan faktor pembatas karena tersedianya pilihan bagi nelayan pemilik untuk mempekerjakan orang lain. Sementara relasi antara sesama nelayan buruh terjadi akibat perbedaan pengetahuan yang dimiliki oleh masing-masing buruh. Perbedaan pengetahuan ini menyebabkan terjadinya pengorganisasian kerja dan terbentuknya peran-peran di dalam proses produksi. Buruh yang memiliki kualifikasi tertentu menduduki satu peran tertentu yang lebih tinggi dibanding buruh lainnya. Relasi antara nelayan pemilik dengan pedagang lebih didominasi oleh akses terhadap pasar. Perbedaan penguasaan dan kekuatan kapital di dalam keseluruhan proses produksi berpengaruh atas besaran distribusi surplus manfaat yang diterima oleh setiap aktor.

\section{Kultur dan Sistem Nilai Masyarakat Latuhalat, Ambon}

Nelayan Ambon pada umunya merupakan nelayan yang rasional, artinya mereka sangat memperhitungkan keuntungan yang akan mereka raih ketika mereka melakukan suatu tindakan. Nelayan lebih mementingkan investasi terhadap usahanya yang menurut pandangan mereka akan memberikan keuntungan materi daripada melakukan investasi di luar usahanya seperti pendidikan dan perbaikan tempat tinggal. Seorang nelayan (AM) mengatakan :

'....tidak mau kuliah, kuliah kan rugi uang, kalau dilaut, satu hari bisa dapat uang banyak..'

Hal ini berdampak pada anak keturunannya, semua anaknya yang berjumlah sembilan hanya bersekolah sampai tingkat sekolah menengah tingkat pertama (SMP).

Hal ini juga terkait erat dengan pandangan mengenai status sosial seseorang dalam masyarakat Latuhalat. Orang kaya lebih dihormati atau disegani dibandingkan dengan orang yang berpendidikan ataupun seorang bangsawan (keturunan raja).

'...orang disegani karena kekayaannya. Jika kaya, orang akan segan dan horma kepadanya, bukan dari marganya. Raja dibanding dengan duit lebih dihormati duit...' 
Masyarakat terbagi ke dalam pelapisan-pelapisan atau yang biasa disebut stratifikasi. Stratifikasi sosial menurut Talcot Parson, merupakan pemeringkatan masyarakat dalam kaitannya dengan nilai-nilai kebudayaan bersama dan hubungan normatifnya memunculkan hubungan"kelas" (Scott, 2011). Skala dalam stratifikasi sosial yang ada dipengaruhi oleh "sistem nilai yang terpenting ". Sistem pelapisan itu sendiri dapat bersifat tertutup (closed social stratification) dan terbuka (open social stratification). Dikatakan tertutup jika tidak memungkinkan seseorang untuk berpindah dari satu strata ke strata lainnya, sebaliknya terbuka jika memungkinkan anggotanya untuk berpindah dari satu lapisan ke lapisan lainnya. Pelapisan tersebut di dalamnya menujukkan kelas dan status seseorang. Ada dua macam status di dalam masyarakat, yaitu

a. Ascribed status, yaitu status yang diperoleh karena kelahiran. Status ini umumnya ada ditengah masyarakat yang menerapkan pelapisan bersifat tertutup. Contohnya status kebangsawanan.

b. Achieved status adalah status yang diperoleh melalui usaha yang disengaja, bersifat terbuka bagi siapa saja (Soekanto, 2009)

Berdasarkan teori di atas, masyarakat negeri Latuhalat merupakan masyarakat yang memiliki sistem pelapisan terbuka yang memungkinkan adanya perpindahan status sosial anggotanya. Status yang menjadi dasar pelapisan mereka adalah achieved status yang diperoleh melalui usaha, dalam hal ini kekayaan yang diperoleh melalui usaha atau mata pencaharian mereka. Status kebangsawanan tidak menjadi dasar dalam sistem pelapisan sosial mereka. Oleh karena itu, dimungkinkan adanya perpindahan dari satu lapisan ke lapisan lainnya dalam suatu sistem startifikasi atau yang dalam istilah sosiologi biasa disebut gerak sosial. Namun demikian mereka sangat mementingkan hiburan sehingga sebagian hasil usahanya dihabiskan untuk membeli sarana hiburan, seperti tape, dvd/vcd, sound system dan alat elektronik lainnya. Kepemilikan alat tersebut dapat menjadi salah satu prestis yang bisa menunjukkan status sosial seseorang. Selain itu hiburan dapat pula diperoleh dengan layanan jasa seperti karaoke dan hiburan malam.

Alokasi biaya untuk hiburan ini diperoleh dari penjualan 'ikan makan'. Ikan makan adalah ikan sampingan dari hasil tangkapan, atau ikan yang bukan merupakan hasil tangkapan utama. Ikan ini juga merupakan ikan bagian nelayan untuk dibawa ke rumah. Para istri dari nelayan mengetahui adanya 'ikan makan' ini, namun mereka mengerti bahwa hiburan merupakan kebutuhan bagi suaminya setelah mereka bekerja keras di laut sehingga para istri tidak ikut campur mengelola 'ikan makan'.

Nelayan memiliki beberapa kepercayaan saat mereka melaut, diantaranya adalah:
1. Tidak diperbolehkan membuang sisa ikan dari bekal makanan karena akan mengusir ikan yang lain

2. Pada waktu suami melaut, istri di rumah harus bersikap baik pada anak-anaknya. Ada anggapan bahwa ikan yang lepas dari tangkapan merupakan akibat dari adanya keributan antara ibu dan anak.

3. Ikan hasil tangkapan pertama tidak boleh dilepas

4. Antar ABK dilarang bertengkar, karena dipercaya ikan akan hilang sehingga mereka tidak akan mendapatkan hasil tangkapan

5. Berbicara kasar, memaki, karena orang tetua di laut akan marah

6. Nelayan mempercayai adanya hantu laut berupa cahaya yang dipercaya cahaya tersebut dapat membuat mereka tersesat jika mereka mencoba menghampirinya.

7. Pantangan tersebut menunjukkan beberapa hal:

8. Adanya hubungan saling mempengaruhi anatara kehidupan di darat dan kehidupan di laut

9. Adanya kekuatan supranatural di laut yang mempengaruhi hasil tangkapan dan keselamatan para nelayan

Kepercayaan tersebut mendorong mereka melakukan aktivitas ritual yang dianggap dapat menghindarkan mereka dari bahaya dan mendapatkan hasil tangkapan yang maksimal. Diantaranya adalah ritual selamatan kapal yang dilaksanakan saat kapal pertama kali diluncurkan (turun kapal).

Hal yang menjadi sorotan dari hasil identifikasi di lokasi penelitian terkait kultur yang ada, yaitu adanya perilaku dan mentalitas untuk maju. Hal ini terlihat dari adanya keinginan dan upaya untuk berinvestasi yang bertujuan memperbesar skala usaha yang telah dimiliki. Beberapa kasus yang ada juga ditemui beralihnya seseorang dari status buruh nelayan menjadi nelayan pemilik.

\section{KESIMPULAN DAN REKOMENDASI KEBIJAKAN}

\section{Kesimpulan}

Masyarakat di Negeri Latuhalat memiliki ciriciri yang berada diantara masyarakat tradisional pedesaan dengan dicirikan kolektifitas yang tinggi, struktur ekonomi lokal berupa kecenderungan ekonomi pertukaran dan lainnya; juga memiliki ciri-ciri yang menjadi pra syarat dari masyarakat industri, seperti kemampuan berinvestasi, tidak mudah menyerah, kemampuan adaptasi dan inovasi. Berdasarkan ciri-ciri tersebut maka dapat disimpulkan masyarakat di Negeri Latuhalat masuk kedalam kategori tipologi masyarakat peralihan dari masyarakat tradisional pedesaan menuju masyarakat industri. 
Permasalahan yang ditemui di Negeri Latuhalat terdiri dari permasalahan sumber daya yang dirasa setiap tahun semakin menurun, tidak menentu musim penangkapan, dan semakin jauhnya daerah fishing ground; permasalahan struktural yang terdiri dari keterbatasan akses permodalan bagi aktor-aktor yang ada menyebabkan tidak berjalannya program-program pemerintah yang bertujuan untuk membantu masyarakat seperti halnya penguasaan teknologi dan pengetahuan oleh segilintir orang di dalam kelompok usaha membuat permasalahan baru dan berpotensi menimbulkan kecemburuan sosial; sementara permasalahan kultural lebih mengarah kepada masih adanya budaya konsumtif yang lebih besar dibandingkan dengan budaya investasi secara keseluruhan.

\section{Rekomendasi Kebijakan}

Rekomendasi kebijakan yang diajukan terkait tipologi masyarakat peralihan dan permasalahan sumber daya, struktural dan kultural adalah meliputi pendidikan, akses permodalan, dan akses pasar barang produksi sebagai entry point upaya perbaikan dan rekayasa sosial pada masyarakat di Negeri Latuhalat.

\section{DAFTAR PUSTAKA}

Anonymous, 2011. Apa dan Bagaimana MP3El. Dalam Sustaining Partnership. Media Informasi Kerjasama Pemerintah dan Swasta. Edisi Khusus Konektivitas Nasional. 2011. Bappenas. Jakarta.

Damsar, 2002. Sosiologi Ekonomi. Edisi Revisi. PT Raja Grafindo Persada. Jakarta.

Granovetter, M. 1992. Economic Action and Social Structure: The Problem of Embeddedness. dalam M. Granovetter dan R. Swedberg (Eds). The Sociology of Economic Life. pp. 53-81. Westview Press Inc. Boulder-San FransiscoOxford.

Kuncoro, M. 2009. Metode Riset untuk Bisnis \& Ekonomi: Bagaimana Meneliti \& Menulis Tesis?. Penerbit Erlangga. Edisi 3. Cetakan 1. Jakarta.

Scott John. 2011. Sosiologi: The Key Concepts. PT Raja Grafindo Persada. JakartaSingarimbun, M., dan S. Effendi (Eds). 1989. Metode Penelitian Survei, Penerbit LP3ES. Edisi Revisi, Cetakan 1. Jakarta.

Soekanto Soejono. 2009. Sosiologi: Suatu Pengantar. PT. RajaGrafindo Persada. Jakarta 